\title{
Front Matter: Volume 9384
}

, "Front Matter: Volume 9384," Proc. SPIE 9384, Emerging Liquid Crystal Technologies X, 938401 (22 April 2015); doi: 10.1117/12.2192910

SPIE. Event: SPIE OPTO, 2015, San Francisco, California, United States 


\title{
PROCEEDINGS OF SPIE
}

\section{Emerging Liquid Crystal Technologies $X$}

\author{
Liang-Chy Chien \\ Harry J. Coles \\ Hirotsugu Kikuchi \\ Ivan I. Smalyukh \\ Editors
}

9-11 February 2015

San Francisco, California, United States

Sponsored and Published by

SPIE 
The papers included in this volume were part of the technical conference cited on the cover and title page. Papers were selected and subject to review by the editors and conference program committee. Some conference presentations may not be available for publication. The papers published in these proceedings reflect the work and thoughts of the authors and are published herein as submitted. The publisher is not responsible for the validity of the information or for any outcomes resulting from reliance thereon.

Please use the following format to cite material from this book:

Author(s), "Title of Paper," in Emerging Liquid Crystal Technologies X, edited by Liang-Chy Chien, Harry J. Coles, Hirotsugu Kikuchi, Ivan I. Smalyukh, Proceedings of SPIE Vol. 9384 (SPIE, Bellingham, WA, 2015) Article CID Number.

ISSN: 0277-786X

ISBN: 9781628414745

\section{Published by}

\section{SPIE}

P.O. Box 10, Bellingham, Washington 98227-0010 USA

Telephone +1 3606763290 (Pacific Time) · Fax +1 3606471445

SPIE.org

Copyright @ 2015, Society of Photo-Optical Instrumentation Engineers.

Copying of material in this book for internal or personal use, or for the internal or personal use of specific clients, beyond the fair use provisions granted by the U.S. Copyright Law is authorized by SPIE subject to payment of copying fees. The Transactional Reporting Service base fee for this volume is $\$ 18.00$ per article (or portion thereof), which should be paid directly to the Copyright Clearance Center (CCC), 222 Rosewood Drive, Danvers, MA 01923. Payment may also be made electronically through CCC Online at copyright.com. Other copying for republication, resale, advertising or promotion, or any form of systematic or multiple reproduction of any material in this book is prohibited except with permission in writing from the publisher. The CCC fee code is 0277-786X/15/\$18.00.

Printed in the United States of America.

Publication of record for individual papers is online in the SPIE Digital Library.

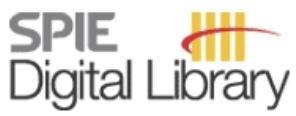

SPIEDigitalLibrary.org

Paper Numbering: Proceedings of SPIE follow an e-First publication model, with papers published first online and then in print. Papers are published as they are submitted and meet publication criteria. A unique citation identifier (CID) number is assigned to each article at the time of the first publication. Utilization of CIDs allows articles to be fully citable as soon as they are published online, and connects the same identifier to all online, print, and electronic versions of the publication. SPIE uses a six-digit CID article numbering system in which:

- The first four digits correspond to the SPIE volume number.

- The last two digits indicate publication order within the volume using a Base 36 numbering

system employing both numerals and letters. These two-number sets start with 00, 01, 02, 03, 04, $05,06,07,08,09,0 A, 0 B \ldots$. OZ, followed by 10-1Z, 20-2Z, etc.

The CID Number appears on each page of the manuscript. The complete citation is used on the first page, and an abbreviated version on subsequent pages. 


\title{
Contents
}

\author{
$\checkmark \quad$ Authors \\ vii Conference Committee \\ ix Introduction
}

\section{SESSION 1 NANOPARTICLES DOPED SYSTEMS}

938402 Nematic topological line defects as optical waveguides (Keynote Paper) [9384-1]

SESSION 2 SOFT MECHANICS AND METAMATERIALS

938406 Surface dynamics and mechanics in liquid crystal polymer coatings (Invited Paper) [9384-5]

9384 OA Single-photon experiments with liquid crystals for quantum science and quantum engineering applications (Invited Paper) [9384-46]

\section{SESSION 3 NEW MATERIALS AND EFFECTS}

9384 OB Light-directing self-organized 1D and 3D chiral liquid crystalline nanostructures (Keynote Paper) [9384-9]

$9384 \mathrm{OE}$ Thin film polarizer and color filter based on photo-polymerizable nematic liquid crystal [9384-12]

\section{SESSION 4 CHIRAL PHASES AND APPLICATIONS}

$9384 \mathrm{OH} \quad$ Stabilizing blue phase liquid crystals with linearly polarized UV light (Invited Paper) [9384-15]

9384 Ol Electro-optical behavior of polymer dispersed blue phase liquid crystals [9384-16]

9384 0J Field-induced Bragg diffraction in polymer stabilized cholesteric liquid crystal bubbles [9384-17]

\section{SESSION 5 WAVEGUIDES AND SPATIAL LIGHT MODULATORS}

$9384 \mathrm{OL} \quad$ Liquid crystal waveguide technologies for a new generation of low-power photonic integrated circuits (Invited Paper) [9384-19] 
9384 OM Emerging liquid crystal waveguide technology for low SWaP active short-wave infrared imagers [9384-20]

9384 ON Fast-response IR spatial light modulators with a polymer network liquid crystal [9384-21]

\section{SESSION 6 ACTIVE FILTERS AND RETARDERS}

$9384 \mathrm{OQ}$ Liquid crystal photonics with indium tin oxide nanowhiskers and graphene as functional electrodes (Invited Paper) [9384-23]

9384 OT Dynamic and complex optical patterns from colloids of cholesteric liquid crystal droplets (Invited Paper) [9384-45]

\section{SESSION 7 FAST-SWITCHING AND BISTABLE DEVICES}

9384 OU Nanosecond electric modification of order parameter in nematic and isotropic phases of materials with negative and positive dielectric anisotropy (Keynote Paper) [9384-28]

$93840 \mathrm{~V}$ Fast bistable switching of a chiral-nematic liquid crystal cell induced by applying an in-plane electric field [9384-39]

9384 OW Wide-color gamut multi-twist retarders [9384-30]

\section{SESSION $8 \quad$ LENS AND 3D DISPLAYS}

938410 A liquid crystal and polymer composite film for liquid crystal lenses (Invited Paper) [9384-34]

938411 An electrically tunable liquid crystal lens coupler for the fiber communication systems [9384-35]

938412 Super-fast refresh holographic liquid crystals for holographic 3D display [9384-36]

938413 A polarized liquid crystal lens with electrically switching mode and optically written mode [9384-37]

POSTER SESSION

938416 Fast gray-to-gray switching of a hybrid-aligned liquid crystal cell [9384-29]

938417 Double-layered liquid crystal light shutter for control of absorption and scattering of the light incident to a transparent display device [9384-40] 


\section{Authors}

Numbers in the index correspond to the last two digits of the six-digit citation identifier (CID) article numbering system used in Proceedings of SPIE. The first four digits reflect the volume number. Base 36 numbering is employed for the last two digits and indicates the order of articles within the volume. Numbers start with 00, 01, 02, 03, 04, 05, 06, 07, 08, 09, 0A, 0B...0Z, followed by 10-1Z, 20-2Z, etc.

Asquini, Rita, OL

Beccherelli, Romeo, OL

Beeckman, Jeroen, $\mathrm{OE}$

Bisoyi, Hari Krishna, OB

Bissell, Luke J., OA

Borshch, Volodymyr, OU

Boyd, Robert W., OA

Brickson, Leandra L., OW

Broer, Dirk J., 06

Čančula, Miha, 02

Chang, Chia-Ming, 10, 13

Chen, Chyong-Hua, 11

Chen, Haiwei, ON

Chen, Hung-Shan, 10, 13

Chen, Michael, 11

Chien, Liang-Chy, Ol, OJ

Chigrinov, Vladimir Grigorievich, 13

Choi, Tae-Hoon, 16

Civita, Luca, OL

d'Alessandro, Antonio, OL

Davis, Scott R., OM

Drevensek-Olenik, Irena, ОT

Escuti, Michael J., OW

Gao, Hongyue, 12

Gehring, George M., OA

Hornburg, Kathryn J., OW

Huh, Jae-Won, 17

Keller, Sean D., OM

Kemiklioglu, E., 이

Kim, Jung-Wook, 16

Lagerwall, Jan P. F., OT

Lavrentovich, Oleg D., OU

Li, Bing-Xiang, OU

Li, Quan, OB

Liapis, Andreas C., OA

Lin, Yi-Hsin, 10, 11, 13

Liu, Danqing, 06

Liu, Jicheng, 12

Liv, Pan, 12

Lukishova, Svetlana G., OA

Lynch, Ted, OM

Martini, Luca, OL

Mohammadimasoudi, Mohammad, OE

Neyts, Kristiaan, OE

Noh, JungHyun, OT

Oh, Seung-Won, OV

Pan, Ci-Ling, $O Q$

Pan, Ru-Pin, $0 Q$

Peng, Fenglin, ON
Pino, Juan, OM

Ravnik, Miha, 02

Rommel, Scott D., OM

Schadt, Martin, $\mathrm{OH}$

Shin, Dong-Myung, 17

Shiyanovskii, Sergij V., oU

Srivastava, Abhishek Kumar, 13

Sun, Jia Tong, 13

Tripathi, Suvagata, ON

Twieg, Robert J., ON

Uyeno, Gerald P., OM

Varanytsia, Andrii, OJ

Wang, Yu-Jen, 10, 13

Winkler, Justin M., OA

Wu, Shin-Tson, $\mathrm{OH}, \mathrm{ON}$

$\mathrm{XU}$, Daming, $\mathrm{OH}$

Yamamoto, Jun, OT

Yan, Jing, $\mathrm{OH}$

Yang, Chan-Shan, $\mathrm{OQ}$

Yao, Qiuxiang, 12

Yoon, Tae-Hoon, 0V, 16, 17

Yu, Byeong-Hun, 17

Yu, Yingjie, 12

Yuan, Jiamin, $\mathrm{OH}$

Zeng, Chao, 12

Zheng, Huadong, 12

Žumer, Slobodan, 02 
Proc. of SPIE Vol. $9384938401-6$

Downloaded From: https://www.spiedigitallibrary.org/conference-proceedings-of-spie on 26 Apr 2023 Terms of Use: https://www.spiedigitallibrary.org/terms-of-use 


\section{Conference Committee}

Symposium Chairs

David L. Andrews, University of East Anglia (United Kingdom)

Alexei L. Glebov, OptiGrate Corporation (United States)

Symposium Co-chairs

Jean-Emmanuel Broquin, IMEP-LAHC (France)

Shibin Jiang, AdValue Photonics, Inc. (United States)

Program Track Chair

Liang-Chy Chien, Kent State University (United States)

Conference Chair

Liang-Chy Chien, Kent State University (United States)

Conference Co-chairs

Harry J. Coles, University of Cambridge (United Kingdom)

Hirotsugu Kikuchi, Kyushu University (Japan)

Ivan I. Smalyukh, University of Colorado at Boulder (United States)

Conference Program Committee

Dick J. Broer, Technische Universiteit Eindhoven (Netherlands)

Vladimir G. Chigrinov, Hong Kong University of Science and

Technology (Hong Kong, China)

Antonio Martins Figueiredo Neto, Universidade de São Paulo (Brazil)

Andy Y. G. Fuh, National Cheng Kung University (Taiwan)

Heinz S. Kitzerow, Universität Paderborn (Germany)

Jan P. Lagerwall, Seoul National University (Korea, Republic of)

Yi-Hsin Lin, National Chiao Tung University (Taiwan)

Yan-Qing Lu, Nanjing University (China)

Kristiaan Neyts, Universiteit Gent (Belgium)

Masanori Ozaki, Osaka University (Japan)

Ci-Ling Pan, National Tsing Hua University (Taiwan)

Miha Ravnik, University of Ljubljana (Slovenia)

Richard Sutherland, Mount Vernon Nazarene University

(United States)

Nelson V. Tabiryan, BEAM Engineering for Advanced Measurements Company (United States) 
Timothy J. White, Air Force Research Laboratory (United States)

Ming Hsien Wu, Hamamatsu Corporation (United States)

Shin-Tson Wu, CREOL, The College of Optics and Photonics, University of Central Florida (United States)

Huai Yang, Peking University (China)

Hiroshi Yokoyama, Kent State University (United States)

Tae-Hoon Yoon, Pusan National University (Korea, Republic of)

Yanlei Yu, Fudan University (China)

\section{Session Chairs}

$1 \quad$ Nanoparticles Doped Systems

Oleg Lavrentovich, Kent State University (United States)

2 Soft Mechanics and Metamaterials

Slobodan Žumer, University of Ljubljana (Slovenia)

3 New Materials and Effects

Hirotsugu Kikuchi, Kyushu University (Japan)

4 Chiral Phases and Applications

Dick J. Broer, Technische Universiteit Eindhoven (Netherlands)

5 Waveguides and Spatial Light Modulators

Michael J. Escuti, North Carolina State University (United States)

6 Active Filters and Retarders

Andy Ying-Guey Fuh, National Cheng Kung University (Taiwan)

Timothy J. Bunning, Air Force Research Laboratory (United States)

$7 \quad$ Fast-Switching and Bistable Devices

Tae-Hoon Yoon, Pusan National University (Korea, Republic of)

8 Lens and 3D Displays

Kristiaan Neyts, Universiteit Gent (Belgium) 


\section{Introduction}

As the world's leading conference in liquid crystal optics, photonics and displays, the 2015 SPIE Photonics West "Emerging Liquid Crystal Technologies X" conference successfully drew a large and enthusiastic crowd. The conference provided a platform for intellectual and enlightening discussions of current state and exploration of emerging frontiers of liquid crystal science and technologies in optics, photonics and displays.

The scientific program featured keynote, invited and contributed papers, which covered a wide range of topics such as Nanoparticles Doped Systems, Soft Mechanics and Metamaterials, New Materials and Effects, Chiral Phases and Applications, Waveguides and Spatial Light Modulators, Active Filters and Retarders, Fast-Switching and Bistable Devices, and Lens and 3D Displays. The group of participants included a good number of invited speakers, junior scientists and graduate students who gave their research presentations at the conference. Student papers presented at both the oral and poster sessions drew large

attendance and heavy traffic. I highly appreciate the program co-chairs and committee members for their contributions, which are the foundation of this successful conference.

We look forward to seeing you at the Emerging Liquid Crystal Technologies XI conference in 2016.

\section{Liang-Chy Chien Harry J. Coles Hirotsugu Kikuchi Ivan I. Smalyukh}


Proc. of SPIE Vol. $9384938401-10$

Downloaded From: https://www.spiedigitallibrary.org/conference-proceedings-of-spie on 26 Apr 2023 Terms of Use: https://www.spiedigitallibrary.org/terms-of-use 